\title{
Solenosmilia variabilis-bearing cold-water coral mounds off Brazil
}

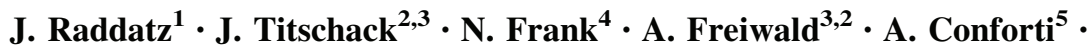

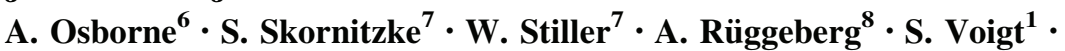 \\ A. L. S. Albuquerque ${ }^{9} \cdot$ A. Vertino ${ }^{10,11} \cdot$ A. Schröder-Ritzrau ${ }^{4} \cdot$ A. Bahr $^{12}$
}

\begin{abstract}
Cold-water corals (CWC), dominantly Desmophyllum pertusum (previously Lophelia pertusa), and their mounds have been in the focus of marine research during the last two decades; however, little is known about the mound-forming capacity of other CWC species. Here, we present new ${ }^{230} \mathrm{Th} / \mathrm{U}$ age constraints of the relatively rarely studied framework-building CWC Solenosmilia variabilis from a mound structure off the Brazilian margin combined with computed tomography (CT) acquisition. Our results
\end{abstract}

Electronic supplementary material

$\triangle$ J. Raddatz

raddatz@em.uni-frankfurt.de

1 Institute of Geosciences, Goethe University Frankfurt, Altenhöferallee 1, 60438 Frankfurt am Main, Germany

2 MARUM - Center for Marine Environmental Sciences, University of Bremen, Leobener Str. 8, 28359 Bremen, Germany

3 Marine Research Department, Senckenberg am Meer, Südstrand 40, 26382 Wilhelmshaven, Germany

4 Institut für Umweltphysik, Universität Heidelberg, Im Neuenheimer Feld 229, 69120 Heidelberg, Germany

5 Istituto per lo studio degli impatti Antropici e Sostenibilità in ambiente marino, Consiglio Nazionale delle Ricerche (IAS CNR), loc. Sa Mardini Torregrande, Oristano, Italy

6 GEOMAR Helmholtz Centre for Ocean Research, Wischhofstraße 1-3, 24148 Kiel, Germany

7 Diagnostic and Interventional Radiology (DIR), Heidelberg University Hospital, Im Neuenheimer Feld 110, 69120 Heidelberg, Germany show that $S$. variabilis can also contribute to mound formation, but reveal coral-free intervals of hemipelagic sediment deposits, which is in contrast to most of the previously studied CWC mound structures. We demonstrate that $S$. variabilis only occurs in short episodes of $<4$ kyr characterized by a coral content of up to $31 \mathrm{vol} \%$. In particular, it is possible to identify distinct clusters of enhanced aggradation rates (AR) between 54 and $80 \mathrm{~cm} \mathrm{ka}^{-1}$. The determined AR are close to the maximal growth rates of individual $S$. variabilis specimens, but are still up to one order of magnitude smaller than the AR of $D$. pertusum mounds. Periods of enhanced S. variabilis AR predominantly fall into glacial periods and glacial terminations that were characterized by a $60-90 \mathrm{~m}$ lower sea

8 Department of Geosciences, University of Fribourg, Chemin du Musée 6, 1700 Fribourg, Switzerland

9 Programa de Geociências (Geoquímica), Universidade Federal Fluminense, Niterói, Rio de Janeiro, Brazil

10 Department of Geology, Ghent University, Krijgslaan 281, S8, 9000 Ghent, Belgium

11 Department of Earth and Environmental Sciences, University of Milano-Bicocca, Piazza della Scienza 4, 20126 Milan, Italy

12 Institut für Geowissenschaften, Universität Heidelberg, Im Neuenheimer Feld 234-236, 69120 Heidelberg, Germany 
level. The formation of nearby $D$. pertusum mounds is also associated with the last glacial termination. We suggest that the short-term periods of coral growth and mound formation benefited from enhanced organic matter supply, either from the adjacent exposed shelf and coast and/or from enhanced sea-surface productivity. This organic matter became concentrated on a deeper water-mass boundary between South Atlantic Central Water and the Antarctic Intermediate Water and may have been distributed by a stronger hydrodynamic regime. Finally, periods of enhanced coral mound formation can also be linked to advection of nutrient-rich intermediate water masses that in turn might have (directly or indirectly) further facilitated coral growth and mound formation.

Keywords Cold-water corals · South Atlantic $\cdot{ }^{230} \mathrm{Th} / \mathrm{U}$. Computed tomography

\section{Introduction}

Framework-building scleractinian cold-water corals (CWC) are one of the most important ecosystem engineers of the deep sea (e.g. Freiwald 2002; Roberts et al. 2006; Frank et al. 2011; Hebbeln et al. 2019; Raddatz and Rüggeberg 2019). The initial settlement of CWCs generally occurs on continental slopes and shelves, seamounts or oceanic ridges (Roberts et al. 2006). CWCs have been able to form reef- and mound-like structures on the European (Roberts et al. 2009) and African (Wienberg et al. 2018) continental margin, the Mediterranean (e.g. Freiwald et al. 2009), the Caribbean and in the Gulf of Mexico (e.g. Hebbeln et al. 2014), on the continental margin off South America in the South Atlantic (Viana et al. 1998; Sumida et al. 2004) and have also been reported from the Indian Ocean (e.g. Western Australia, Trotter et al. 2019) and the NE Pacific (e.g. Lumsden et al. 2007). The main constructors of coral mounds are the framework-building CWCs Desmophyllum pertusum (new combination of the former species Lophelia pertusa as suggested by Addamo et al. (2016), that still needs further validation) and Madrepora oculata. Coral mound development strongly depends on the proliferation of the scleractinian CWC species and is a result of the balance between coral growth and sediment input. Furthermore, coral mounds are typically characterized by a composition of $>50 \%$ hemipelagic sediments and loose interspersion of coral fragments and other shell-building organisms (Titschack et al. 2015; Wienberg and Titschack 2017). They can be subdivided into (I) "active" mounds that are characterized by a flourishing coral community and ongoing mound aggradation and (II) "dormant" mounds, which are currently not covered by a vivid coral community and exhibit no significant mound aggradation (Wienberg and Titschack 2017). Here, we follow the terminology of these seabed structures by Wienberg and Titschack (2017) which implies that all three-dimensional structures formed at least periodically by CWCs are termed coral mounds.

Off Brazil, CWC mounds were reported first by Viana et al. (1998) and Sumida et al. (2004). Since then there is growing evidence that the Brazilian continental slope is an important region of vital CWC habitats characterized by a high biodiversity (Kitahara 2006, 2007; Pires 2007; Pires et al. 2014; Carvalho et al. 2016). In particular, on the Brazilian continental margin D. pertusum, Enallopsammia rostrata and $S$. variabilis are the known frameworkbuilding corals (Fig. 1; Freiwald et al. 2017 and references therein; Pires 2007). CWC mounds along the continental slope are found at intermediate water depth between 500 and $1000 \mathrm{~m}$ and are up to $70 \mathrm{~m}$ in height and $180-360 \mathrm{~m}$ in width (Arantes et al. 2009; Sumida et al. 2004; Viana et al. 1998). Mound formation driven by the growth of the CWC $D$. pertusum is documented during the last $25 \mathrm{kyr}$ in the Campos and Santos Basin (Mangini et al. 2010; Henry et al. 2014). In contrast, little is known about the moundforming potential of $S$. variabilis corals. In general, $S$. variabilis occurrences have been reported from the Atlantic, Pacific and Indian Ocean (Fig. 1, Zibrowius 1973, 1980; Cairns 1995; Freiwald et al. 2017; Trotter et al. 2019) and are often associated with $D$. pertusum occurrences, but at greater water depth (Zibrowius 1980; Zibrowius, pers. comm.; Roberts et al. 2009, Freiwald et al. 2017). Best studied are the $S$. variabilis occurrences from the SW Pacific in water depths ranging from 220 to $2165 \mathrm{~m}$ with densest aggregations between 1000 and $1300 \mathrm{~m}$ off New Zealand and Australia (Koslow et al. 2001; Tracey et al. 2011: Bostock et al. 2015; Fallon et al. 2014; Thresher et al. 2014). The environmental controlling factors of modern $S$. variabilis reefs are not well studied. However, $S$. variabilis occurrences appear typically between 3 and $4{ }^{\circ} \mathrm{C}$, which is at least $3{ }^{\circ} \mathrm{C}$ colder than flourishing $D$. pertusum mounds (Fallon et al. 2014; Flögel et al. 2014; Gammon et al. 2018). Moreover, S. variabilis habitats are found in less aragonite saturated waters (Thresher et al. 2011; Bostock et al. 2015; Gammon et al. 2018) compared to flourishing D. pertusum reefs and mounds (Flögel et al. 2014). Nevertheless, whether these different ecological tolerances enable $S$. variabilis to form mounds is unknown. Moreover, a comparison of different framework-building CWCs may further help to constrain factors that promote or inhibit mound formation.

Here, we present a mound that is periodically formed by the CWC $S$. variabilis and (1) reconstruct its temporal development and (2) discuss the environmental controlling factors favourable for its formation. Our study is based on a combination of computed tomography (CT) acquisitions of 


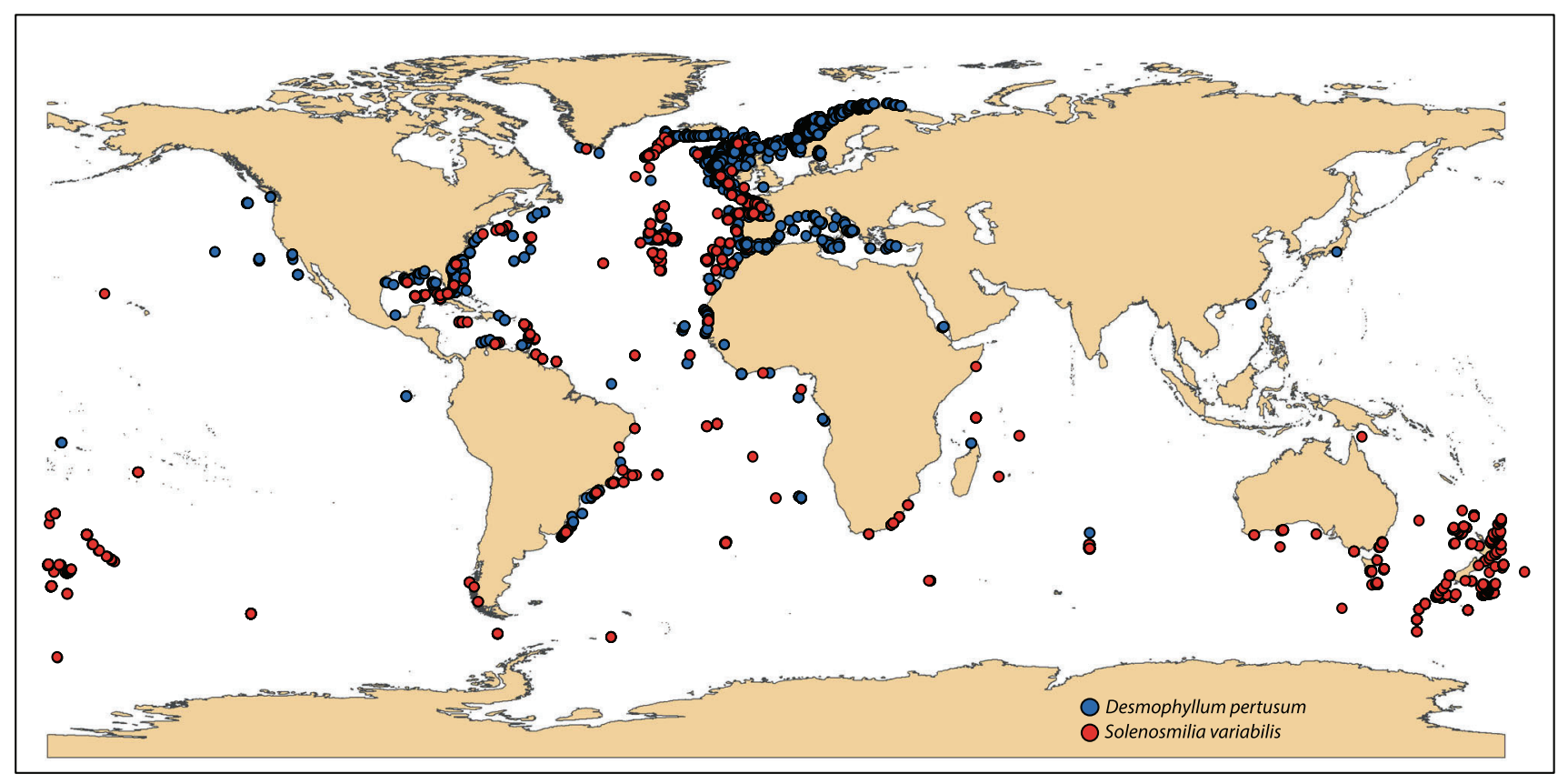

Fig. 1 Global distribution of the scleractinian framework-building cold-water corals Desmophyllum pertusum (blue) and Solenosmilia variabilis $(r e d)$. Data taken from various sources: NIWA Invertebrate

Collection; UNEP Dataset, Freiwald et al. 2017; GloSS Dataset, Freiwald (Unpublished)

a sediment core retrieved from the top of a $25 \mathrm{~m}$ high mound structure (Bowie Mound, Fig. 2, Bahr et al. 2016) and ${ }^{230}$ Thorium/Uranium age determinations on the coral fragments.

\section{Local hydrography}

The ocean circulation along the continental slope of South America at $20^{\circ} \mathrm{S}$ is dominated by the anticyclonic subtropical gyre (Stramma and England 1999; Fig. 2). The Salinity Maximum Water (SMW, $24{ }^{\circ} \mathrm{C}, \sigma_{\theta} \sim 25.2$ ) forms by excess evaporation in the tropics (Worthington 1976) and is transported westward towards the South American coast by the South Equatorial Current (SEC). The SEC bifurcates upon reaching the South American shelf break at approximately $10^{\circ}-14^{\circ} \mathrm{S}$, continuing northwards as the North Brazil (Under) Current and southwards as the Brazil Current (Stramma and England 1999; Rodrigues et al. 2007). SMW occupies the upper $200 \mathrm{~m}$ between $12^{\circ} \mathrm{S}$ and $22^{\circ} \mathrm{S}$ (Mémery et al. 2000). River waters mix with SMW in shelf areas to form lower salinity Subtropical Shelf Water (SSW; Piola et al. 2002; Venancio et al. 2014). Below the SMW, steadily decreasing temperatures and salinities $\left(20^{\circ} \mathrm{C}, 36.0\right.$ psu to $5^{\circ} \mathrm{C}$, 34.3 psu) mark the presence of South Atlantic Central Water (SACW) with contributions from formation areas in the southwest Atlantic and the South Indian Ocean (Stramma and England 1999; Sverdrup et al. 1942). The SACW is underlain by the Antarctic Intermediate Water
(AAIW), which bathes the S. variabilis-bearing Bowie Mound at $866 \mathrm{~m}$ water depth (Fig. 2). Here, the AAIW forms a low salinity layer $(<34.4 \mathrm{psu})$ due to the subduction of cooled surface water of the Antarctic Circumpolar Current between the Antarctic Polar Front (APF) and the Subantarctic Front (SAF), particularly in the vicinity of the Drake Passage and Falkland Current loop. Some AAIW is also supplied to the South Atlantic from the Indian Ocean via the Agulhas Current (Stramma and England. 1999). Upper North Atlantic Deep Water (UNADW) is found below AAIW north of $26^{\circ} \mathrm{S}$ and can be recognized on the basis of higher oxygen concentrations and salinities compared to AAIW (Mémery et al. 2000).

\section{Methods}

During research expedition M125 with the German research vessel METEOR, we retrieved the 5.86-m-long gravity core M125-34-2 (positioning secured by UltraShort-Baseline system, POSIDONIA) from the top of the $25 \mathrm{~m}$ high "Bowie mound" structure in $866 \mathrm{~m}$ water depth at $21^{\circ} 56.957^{\prime} \mathrm{S}$ and $39^{\circ} 53.117^{\prime} \mathrm{W}$ located within a province of mound-like structures (Fig. 2, Bahr et al. 2016). CT images were performed for the sedimentological characterization of the deposits and subsequent ${ }^{230} \mathrm{Th} / \mathrm{U}$ age determinations to temporally constrain mound formation phases and determine mound AR. Additional on-board Conductivity-Temperatures Depth (CTD) profiles at the 

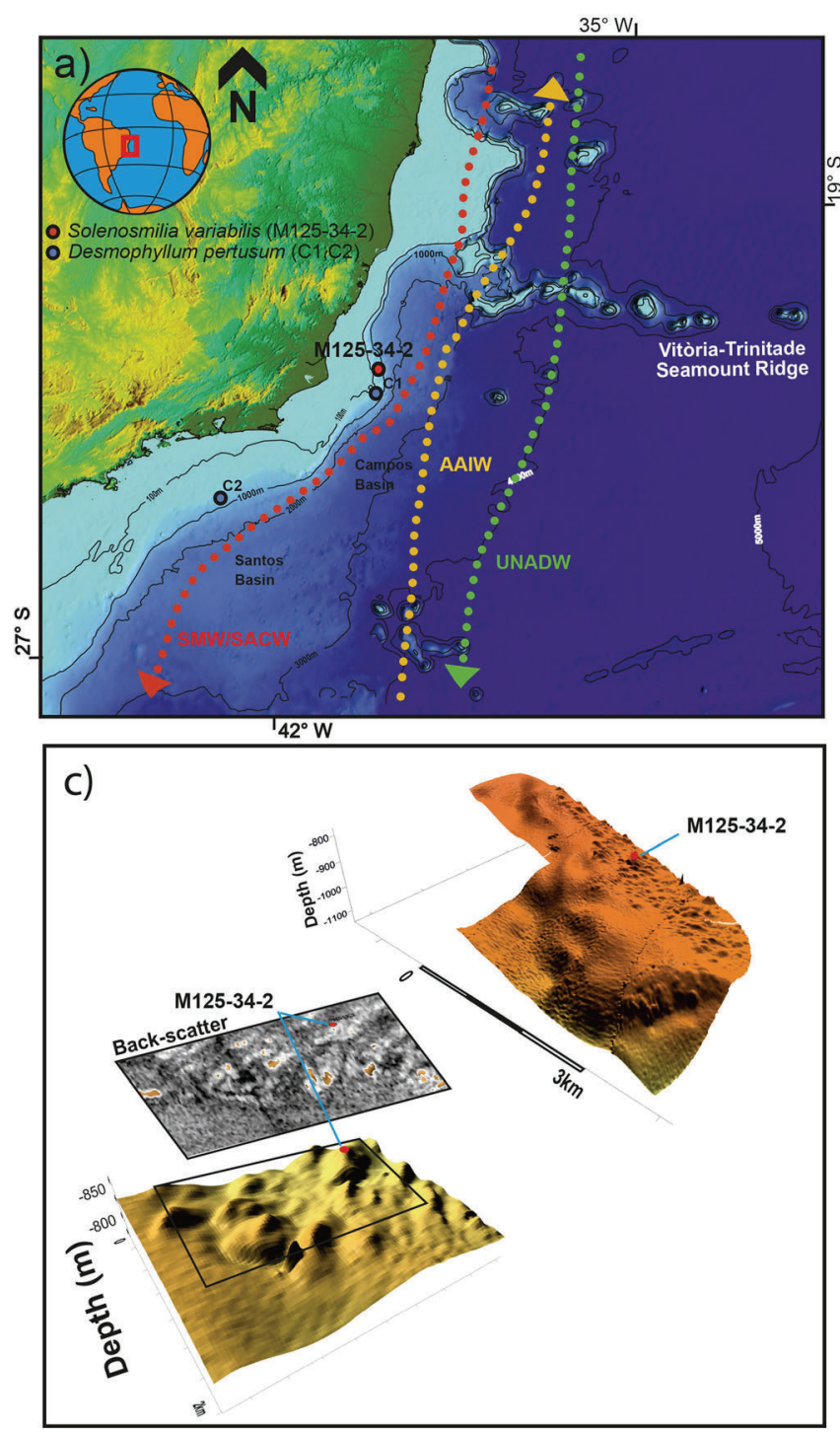

Fig. 2 a Map of study area showing the locations of sediment core M125-34-2 retrieved during research cruise M125 with RV Meteor and two other cold-water coral $D$. pertusum-bearing sediment cores (C1 and C2) investigated by Mangini et al. (2010) and Henry et al. (2014). b Bathymetric map of the coral mound province on the slope of the Campos Basin and the Bowie Mound sampled for this study (Bahr et al. 2016). c Close-up of the bathymetry coral mound

Campos Basin over the Bowie Mound were collected to determine the modern hydrography.

\section{CTD}

A down-slope transect of seven CTD profiles were measured with a Seabird SBE 9 device fitted with two temperature sensors, two conductivity sensors, a pressure sensor, an oxygen sensor and a fluorometer together with a Seabird SBE 11 plus V 5.2 deck unit. Data were taken from the downcasts. In addition to the on-board measured seawater parameters, all carbonate system parameters were
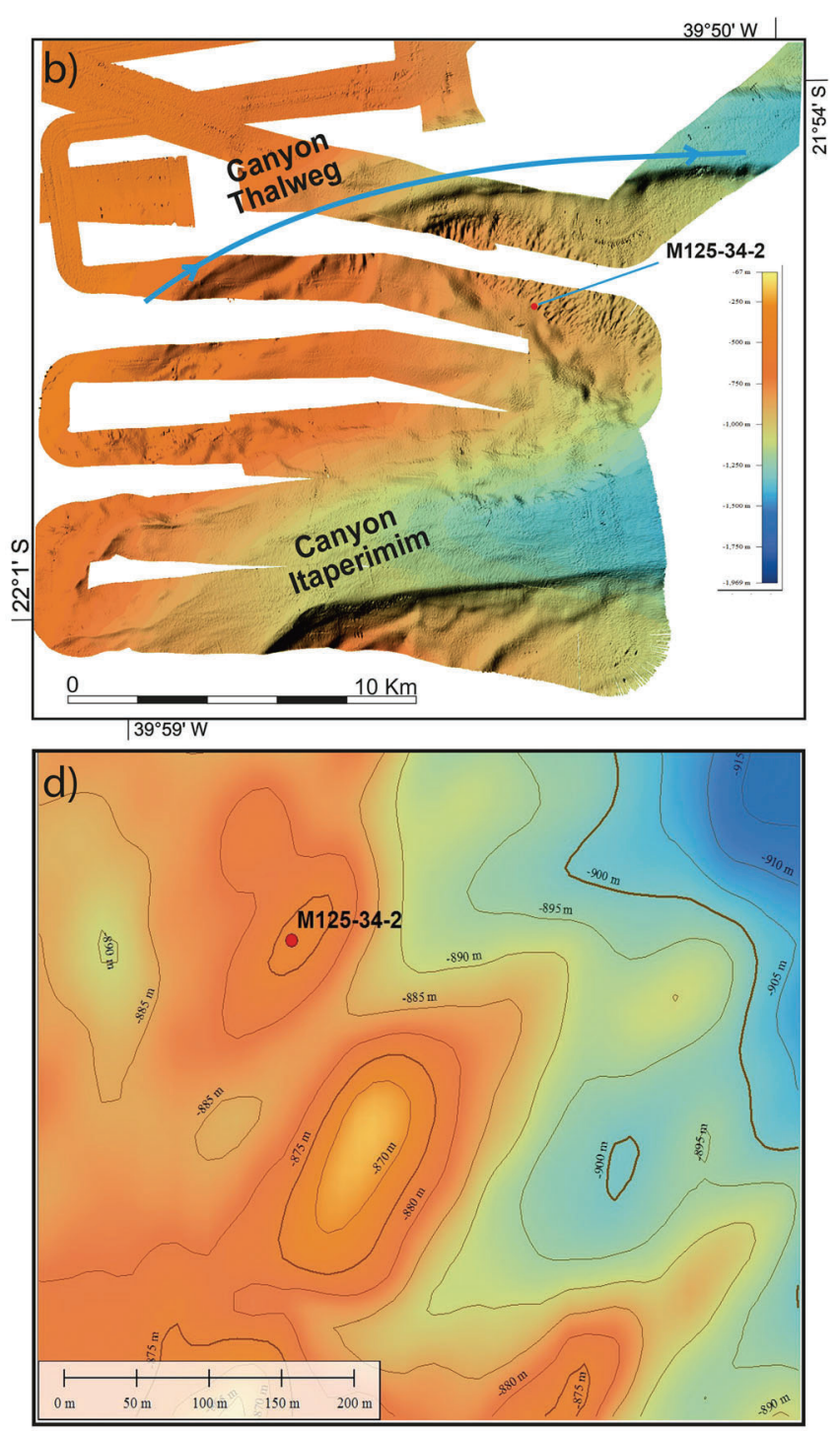

province and the Bowie mound (to right) revealing up to $25 \mathrm{~m}$ high mound structures, the resulting backscatter image highlighting differences in the hardness (upper panel, left) of the seafloor and its topography (lower panel, left). d Detailed multibeam map of the Bowie Mound indicating the core location M125-34-2. The bathymetry was generated with an EM 122 and 702 multibeam echo sounder and a parasound system (MBPS, Bahr et al. (2016)

calculated from existing global datasets (Global alkalinity and $\mathrm{TCO}_{2}$; Goyet et al. 2000) with $\mathrm{CO}_{2}$ sys (Lewis and Wallace 1998).

\section{${ }^{230} \mathrm{Th} / \mathrm{U}$ age determinations}

The sediment surface of station 34 reveals no living corals, but heavily coated and partly dissolved fossil coral fragments of mostly $S$. variabilis, which were not suitable for ${ }^{230} \mathrm{Th} / \mathrm{U}$ age determinations. Samples from the sediment core were selected according to the depositional intervals with enhanced/reduced coral abundances (Section 2.5) 
identified within the CT images. Prior to analyses, all coral samples were cleaned mechanically to remove any contaminants from the skeleton surface (e.g. epibionts, borings, ferro-manganese crusts and coatings) and were then cleaned chemically using weak acid leaching and water rinsing according to the procedure described in Frank et al. (2004), recently updated by Wefing et al. (2017). The measurements were taken at the Institute for Environmental Physics at Heidelberg University (IUP, Germany) on a multi-collector inductively coupled plasma mass spectrometer (ThermoFisher Neptune plus; Wefing et al. 2017). The reproducibility of mass-spectrometric measurements was assessed using the reference material HU-1 (Cheng et al. 2000). In total 36 coral ages have been measured. The ${ }^{232} \mathrm{Th}$ concentrations of all analysed corals ( $\mathrm{N}=34 \mathrm{~S}$. variabilis and $\mathrm{N}=2 \mathrm{M}$. oculata) were always $<4 \mathrm{ppb}$, which is indicative of minor residual contamination with Th either non-carbonate phases (detritus and coating) or seawater. Nevertheless, a correction for initial ${ }^{230} \mathrm{Th}$ was applied prior to age determination using a ${ }^{230} \mathrm{Th} /{ }^{232} \mathrm{Th}$ activity ratio of $8 \pm 4$ (e.g. Mangini et al. 2010; Wefing et al. 2017).

The ${ }^{234} \mathrm{U} /{ }^{238} \mathrm{U}$ activity ratio of all the corals (given as $\delta^{234} \mathrm{U}$, i.e. \%o deviation from secular equilibrium) plot within uncertainty in a narrow band of $\pm 10 \%$ compared to the value of modern seawater (146.8\%o, Fig. 3, electronic supplementary material, Andersen et al. 2010), suggesting closed system behaviour for the exchange of $U$ between the skeletons and seawater or the embedding sediment matrix. Hence, all ages given below are considered reliable.

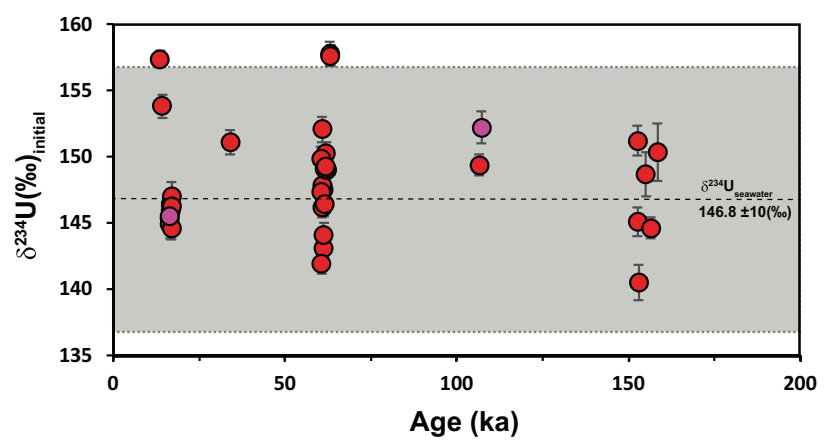

Fig. 3 Calculated $\delta^{234} U_{\text {initial }}$ of the ${ }^{230} \mathrm{Th} / \mathrm{U}$ dates Solenosmilia variabilis (red) and Madrepora oculata (purple) fragments. All samples plot within uncertainty into the $146.8 \pm 10 \%$ envelope (Andersen et al. 2010) and can therefore be considered as reliable. If not visible uncertainties of the ${ }^{230} \mathrm{Th} / \mathrm{U}$ ages and the $\delta^{234} \mathrm{U}_{\text {initial }}$ values are smaller than the dots (see electronic supplementary material)

\section{Computed tomography measurements}

Before opening (cut frozen to avoid core disturbances), sediment core sections were imaged using a CT scanner system (SOMATOM Definition Flash) as described in Skornitzke et al. (2019). Briefly, sediment core sections of $1 \mathrm{~m}$ in length and $12 \mathrm{~cm}$ in diameter were manually aligned with the main axes of the CT scanner's coordinate system using the integrated laser sight system of the CT scanner. Subsequently, image acquisitions were conducted with $140 \mathrm{kV}_{\mathrm{p}}$ tube potential and $570 \mathrm{mAs}$ tube currenttime product with a pitch of 0.4 . The reconstructions of the images were performed iteratively (ADMIRE, Siemens Healthineers) using a sharp kernel (I70 h level 3), a slice thickness/increment of $0.5 \mathrm{~mm} / 0.3 \mathrm{~mm}$, and an isotropic voxel size of $0.35 \mathrm{~mm}$. Further data processing was carried out according to Titschack et al. (2015) using the ZIB edition of the Amira software (Stalling et al. 2005). Briefly, the measured core sections were virtually reunited and the core liner and artefacts due to the coring process were removed ( $2 \mathrm{~mm}$ of the core rim). Furthermore, coral clasts were segmented and separated with the ContourTreeSegmentation module (threshold: 1400; persistence value: 1150) and macrofossils $>2 \mathrm{~cm}$ were visualized as surfaces in 3D (for further methodological details see Titschack et al. 2015).

\section{Results}

\section{Local hydrography and seawater characteristics}

Maximum salinities of 37.3 psu were measured in the upper $20 \mathrm{~m}$ of the study area. Warm $\left(>20^{\circ} \mathrm{C}\right)$ and saline ( $>36 \mathrm{psu}$ ) SMW occupies the upper $150 \mathrm{~m}$ and below this, a steady decline in both temperature and salinity marks the presence of SACW (Fig. 4). The AAIW salinity minimum (34.3 psu) is centred at $\sim 900 \mathrm{~m}$ (Fig. 4). The AAIW also exhibits the lowest oxygen concentrations in the study area $\left(<4.2 \mathrm{~mL} \mathrm{~L}^{-1}\right)$. An increase in oxygen concentrations and salinity below $\sim 1400 \mathrm{~m}$ indicate the contribution of UNADW to the deeper slope region (Fig. 4). At the depths of the coral mound (866 m, taken from Station 25-1 and Station 24-1), potential temperature is $4.3{ }^{\circ} \mathrm{C}$, salinity is $34.34 \mathrm{psu}$, potential density is $27.23 \mathrm{~kg} \mathrm{~m}^{-3}$, and oxygen concentration is $4.60 \mathrm{~mL} \mathrm{~L}^{-1}$ (Fig. 4; Bahr et al. 2016). The Bowie Mound is thus bathed predominantly in AAIW. According to existing datasets (Station $15041,39.5^{\circ} \mathrm{W}, 21.5^{\circ} \mathrm{S}, 900 \mathrm{~m}$ water depth; Goyet et al. 2000), the AAIW at $900 \mathrm{~m}$ water depth has a total alkalinity (TA) of $2287 \mu \mathrm{mol} \mathrm{kg}{ }^{-1}$, dissolved inorganic carbon (DIC) of $2194 \mu \mathrm{mol} \mathrm{kg}{ }^{-1}$, carbonate ion 

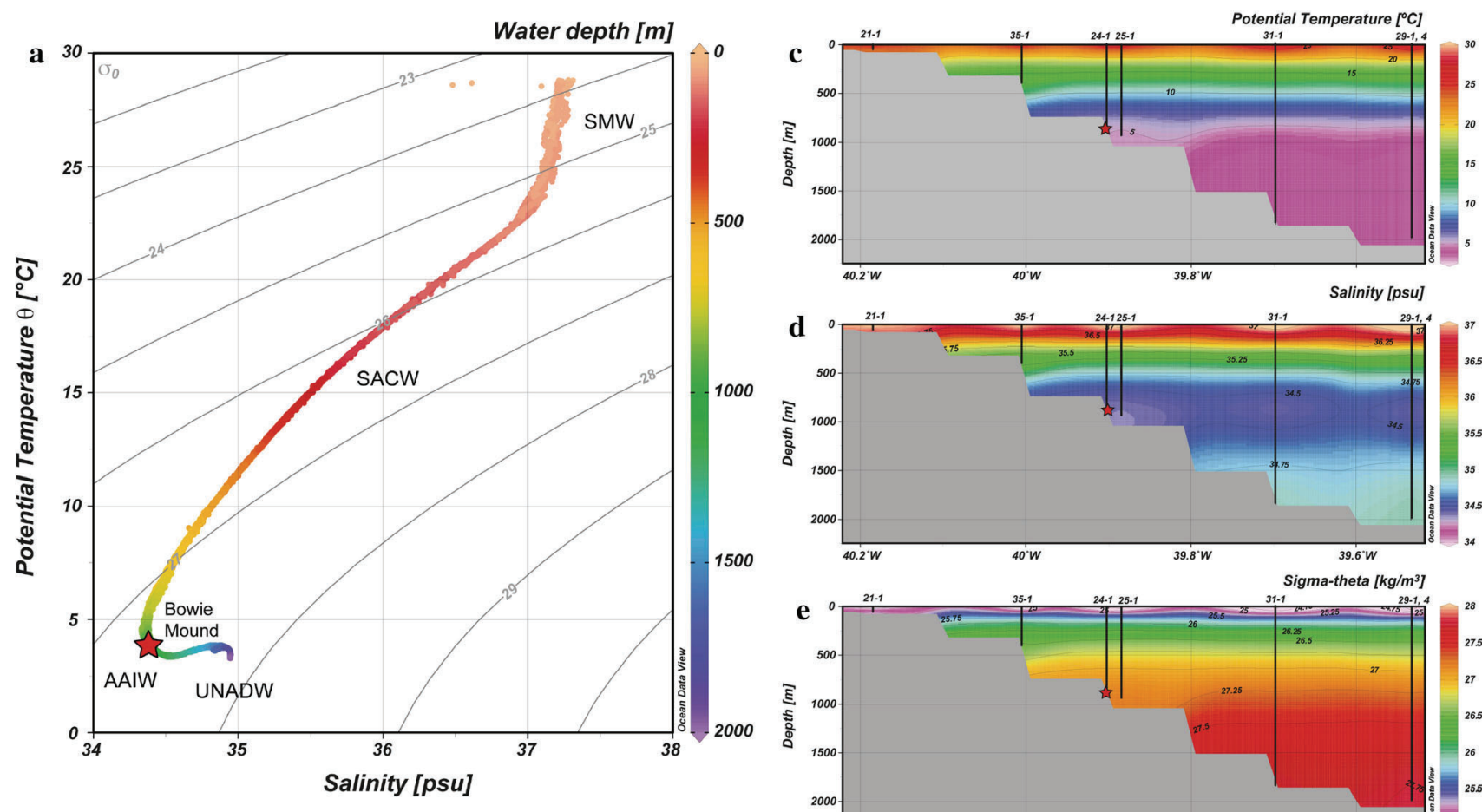

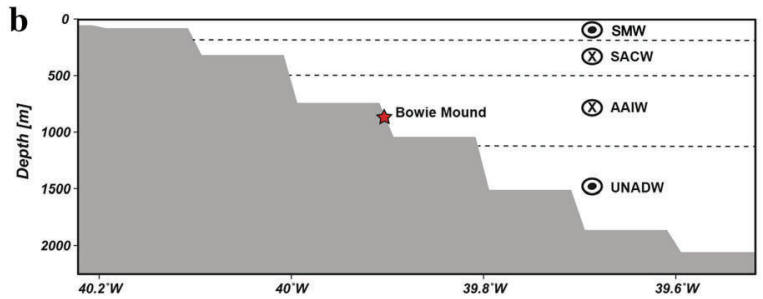

Fig. 4 a Temperature-salinity-depth (TSD) plot including isopycnals of $\sigma_{\Theta}$ of the seven CTD casts in the study area. Red star marks the position of Bowie Mound. Identified water masses are Salinity Maximum Water (SMW), South Atlantic Central Water (SACW), Antarctic Intermediate Water (AAIW), and Upper North Atlantic Deep Water (UNADW). b Downslope section including depth

concentrations $\left(\mathrm{CO}_{3}^{2-}\right)$ of $79 \mu \mathrm{mol} \mathrm{kg}{ }^{-1}$, a $\mathrm{pH}$ value of 7.97 and an aragonite saturation $(\Omega)$ of 1.2 .

\section{Macrofossils clast size and coral content}

The sediment core is characterized by coral-bearing and non-coral-bearing intervals. The sediment is dominantly olive greyish silty clay. Coral-bearing intervals are indicated by the presence of S. variabilis and to a minor degree M. oculata as the major macrofossils (clast length $>2 \mathrm{~cm}$ ), whereas other taxa occur only in very rare quantities (bivalves, gastropods, pteropods). Throughout the entire core, the coral content varies between 0 and $31 \mathrm{vol} \%$. Six coralbearing intervals $\left(\mathrm{C}_{\mathrm{I}}-\mathrm{C}_{\mathrm{VI}}\right)$ were identified within the core (Fig. 5). In detail, $C_{I}$ occurs between 5.5 and $13 \mathrm{~cm}$ with an average coral content of $9 \mathrm{vol} \%$ and maximum of $19 \mathrm{vol} \%$.
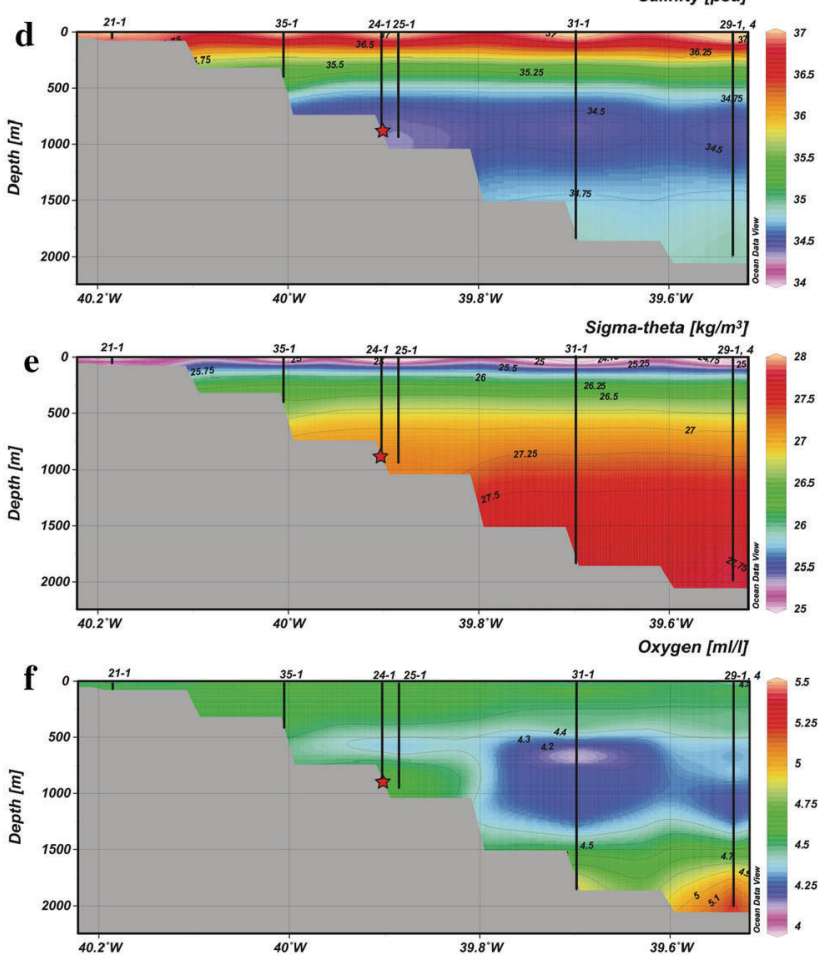

intervals of the ambient water masses and their flow directions. To the right, down-slope sections of the study area showing $\mathbf{c}$ potential temperature, $\mathbf{d}$ salinity, e potential density, and $\mathbf{f}$ oxygen concentrations. In each case the red star marks the seawater properties at the depth of the Bowie Mound. Figures were generated using Ocean Data View (Schlitzer 2017)

$\mathrm{C}_{\text {II }}$ is located at $80-105 \mathrm{~cm}$ with an average coral content of $13 \mathrm{vol} \%$ and a maximum of $23 \mathrm{vol} \%$. Between 131.5 and $138 \mathrm{~cm} \mathrm{C} \mathrm{C}_{\mathrm{III}}$ exhibits coral contents of on average 14 vol\% and a maximum $16 \mathrm{vol} \%$. $\mathrm{C}_{\mathrm{III}}$ is separated from $\mathrm{C}_{\mathrm{IV}}$ by a thin coral-free interval at about $150 \mathrm{~cm}$ core depth. Interval $\mathrm{C}_{\mathrm{IV}}(157 \mathrm{~cm}$ to $190 \mathrm{~cm})$ reveals coral contents of on average $11 \mathrm{vol} \%$ and maximal $23 \mathrm{vol} \%$. The subsequent interval $C_{V}$ between 479.5 and 480.5 has only a minor coral content of maximal $3 \mathrm{vol} \%$, whereas the last interval $\mathrm{C}_{\mathrm{VI}}$ from 549.5 to $568 \mathrm{~cm}$ exhibits coral contents with an average of $13 \mathrm{vol} \%$ and up to a maximum of $31 \mathrm{vol} \%$ at $576 \mathrm{~cm}$. 
Fig. 5 a Downcore ${ }^{230} \mathrm{Th} / \mathrm{U}$ ages of the analysed coral fragments Solenosmilia variabilis (red) and Madrepora oculata (purple) of sediment core M125-34-2. b The calculated aggradation rates (AR) of the different age clusters in $\mathrm{cm} \mathrm{ka}^{-1}$ (orange) and the coral content in vol\% (grey) are plotted against core depth. Note for the calculation of the AR both coral species were used. Also shown are the results of the CT-scans with c sediment surfaces images as well as $\mathbf{d}$ bioclasts $>2 \mathrm{~cm}$. The two smaller figures to the right depict representative intervals of alternating coral-bearing and non-coral-bearing intervals. Below, a picture of the two cold-water corals Madrepora oculata (e) and Solenosmilia variabilis (f) with clearly different morphologies, which are identifiable on CT images. Uncertainties of the ${ }^{230} \mathrm{Th} / \mathrm{U}$ ages are smaller than the dots (see electronic supplementary material)

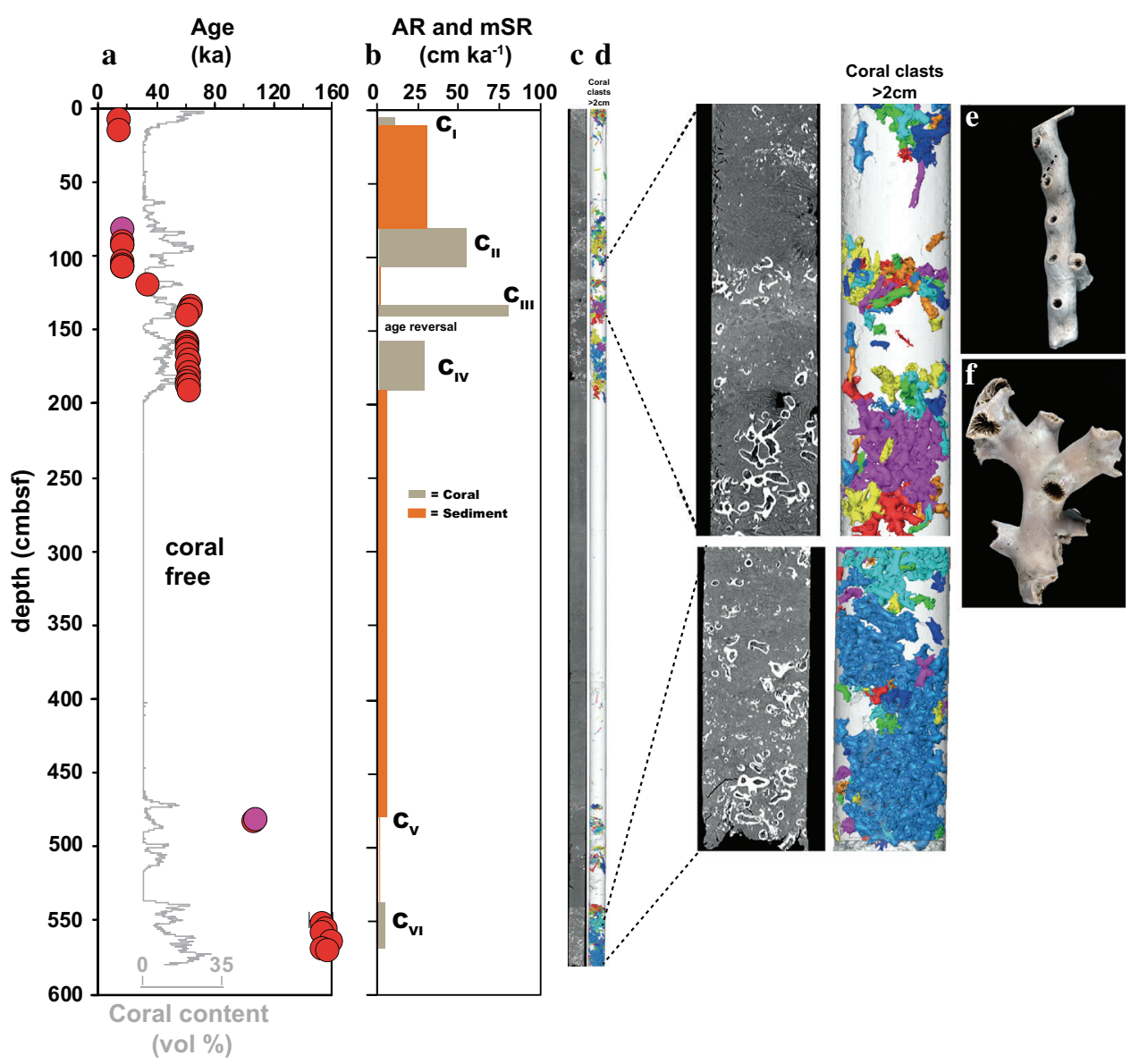

\section{Age constraints}

The ${ }^{230} \mathrm{Th} / \mathrm{U}$ ages increase from 13.65 to $158.41 \mathrm{ka}$ with core depth (Figs. 3 and 5) while the identified coral intervals correspond to six age clusters (Fig. 5). The youngest cluster $\mathrm{C}_{\mathrm{I}}$ provides ages of 13.65 and $14.34 \mathrm{ka}$ for its $7.5 \mathrm{~cm}$ of coral-bearing sediment. The subsequent $67 \mathrm{~cm}$ of hemipelagic sediment corresponds to $2.2 \mathrm{kyr}$ according to the coral ages of $\mathrm{C}_{\mathrm{II}}$, which span from 16.54 to $17.01 \mathrm{ka}$. The next $20 \mathrm{~cm}$ sedimentation without corals covers a period of $>40 \mathrm{kyr}$. The following coral-bearing unit $\mathrm{C}_{\mathrm{III}}$ between 131.5 and $138 \mathrm{~cm}$ appears to be of identical or even older age compared to $\mathrm{C}_{\mathrm{IV}}$. $\mathrm{C}_{\mathrm{III}}$ yields four ages between 61.15 and $63.19 \mathrm{ka}$, whereas $\mathrm{C}_{\mathrm{IV}}(158$ and $190 \mathrm{~cm})$ is constrained by 17 dates revealing ages between 60.53 and $62.2 \mathrm{ka}$, indicating a minor age reversal. Therefore, $\mathrm{C}_{\mathrm{III}}$ has to be considered with caution (Figs. 2, 5) till additional cores or further seismic data that support this finding become available. Coral from unit $C_{V}$ yield ages of 106.62 and $107.14 \mathrm{ka}$ and are separated from the previous unit by $3.9 \mathrm{~m}$ of hemipelagic sediments deposited again roughly in 40 kyr. The final coral-bearing unit $\mathrm{C}_{\mathrm{VI}}$ near the core base at $550 \mathrm{~cm}$ covers a time span ranging from 152.61 to
$156.61 \mathrm{ka}(\mathrm{N}=6$; Fig. 5; Electronic supplementary material). Overall, short periods of coral growth and mound formation are followed by tens of thousands of years of coral absence, dominated by hemipelagic sedimentation.

\section{Aggradation (AR) and sedimentation rates (SR)}

The 36 coral ages obtained build the chronostratigraphic basis to investigate the vertical mound aggradation. We use the concept proposed by Titschack et al. (2015) and Wienberg et al. (2018) for mound formation by frameworkforming corals D. pertusum and M. oculata. Coral-bearing intervals of the Bowie Mound can clearly be identified as they are sharply separated by coral-free deposits. AR were calculated for each coral-bearing interval (including ages from all dated species, hence also M. oculata samples) using the youngest and oldest age and the total thickness of the interval. The resulting AR for the coral-bearing intervals are $11 \mathrm{~cm} \mathrm{kyr}^{-1}\left(\mathrm{C}_{\mathrm{I}}\right), 54 \mathrm{~cm} \mathrm{kyr}^{-1}\left(\mathrm{C}_{\mathrm{II}}\right), 80 \mathrm{~cm} \mathrm{kyr}^{-1}\left(\mathrm{C}_{\mathrm{III}}\right)$, $29 \mathrm{~cm} \mathrm{kyr}^{-1}\left(\mathrm{C}_{\mathrm{IV}}\right), 2 \mathrm{~cm} \mathrm{kyr}^{-1}\left(\mathrm{C}_{\mathrm{V}}\right)$ and $5 \mathrm{~cm} \mathrm{kyr}^{-1}\left(\mathrm{C}_{\mathrm{VI}}\right)$ resulting in a mean $A R$ of $30 \mathrm{~cm} \mathrm{kyr}^{-1}$ and a median value of $20 \mathrm{~cm} \mathrm{kyr}^{-1}$ (including $\mathrm{C}_{\mathrm{III}}$, Fig. 5). 
The intervals without corals can be assumed to reflect continuous sedimentation for which the minimal rates are given by the age difference of the oldest and youngest coral enclosing the section (matrix sedimentation rate, $\mathrm{mSR}$ ). In the intervals between the coral-bearing units $\mathrm{C}_{\mathrm{III}}$ and $\mathrm{C}_{\mathrm{iv}}$ the prominent age reversal inhibits the calculation of a mSR. Overall, mSR is mostly lower than the coral AR and varies between 0.5 and $30 \mathrm{~cm} \mathrm{kyr}^{-1}$ with an mean of $8 \mathrm{~cm}$ $\mathrm{kyr}^{-1}$ and a median value of $2 \mathrm{~cm} \mathrm{kyr}^{-1}$ (Fig. 5). In detail, $\mathrm{mSR}$ is $30 \mathrm{~cm} \mathrm{kyr}^{-1}$ between $\mathrm{C}_{\mathrm{I}} / \mathrm{C}_{\mathrm{II}}$ and $0.7-0.5 \mathrm{~cm} \mathrm{kyr}^{-1}$ between $\mathrm{C}_{\mathrm{II}} / \mathrm{C}_{\mathrm{III}}$ (interrupted by one single coral at $117 \mathrm{~cm}$ with an age of $34.034 \pm 0.144 \mathrm{ka}$ ). Subsequently, mSR varies between $6 \mathrm{~cm} \mathrm{ka}^{-1}$ between coral units $\mathrm{C}_{\mathrm{IV}} / \mathrm{C}_{\mathrm{V}}$ and $2 \mathrm{~cm} \mathrm{kyr}^{-1}$ between coral units $\mathrm{C}_{\mathrm{V}} / \mathrm{C}_{\mathrm{VI}}$.

\section{Discussion}

\section{Coral mounds off Brazil: temporal development}

The first evidence on the temporal occurrence of $S$. variabilis corals off Brazil presented here strongly supports the findings of Mangini et al. (2010) and Henry et al. (2014) and highlights that CWC mound formation at Bowie Mound shows a tendency to occur in relatively short pulses of $<4 \mathrm{kyr}$. This is different from the general formation systematics of CWC mounds in the NE Atlantic Ocean where formation phases during the last $500 \mathrm{kyr}$ occur on interglacial/glacial time scales, predominantly during interglacials at latitudes above $45^{\circ} \mathrm{N}$ and mainly during glacials at low latitudes less than $37^{\circ} \mathrm{N}$ (Rüggeberg et al. 2007; Eisele et al. 2011; Frank et al. 2011; Raddatz et al. 2014, 2016; Wienberg et al. 2009, 2010) with continuous formation phases of $>50 \mathrm{ka}$ (e.g. Wienberg et al. 2018).

Off Brazil, very little information exists with respect to the growth of framework-forming CWCs and the formation of coral mounds. A first study on the temporal occurrence of $D$. pertusum and $M$. oculata has been obtained by Mangini et al. (2010). They pointed out that corals tend to occur within Termination I and are synchronous with the Younger Dryas (YD) cold reversal and Heinrich event 1 (H1). Similar findings have been made for the Mediterranean Sea (McCulloch et al. 2010; Fink et al. 2015; Taviani et al. 2019; Vertino et al. 2019; Wang et al. 2019).

\section{Desmophyllum pertusum versus Solenosmilia variabilis: the influence of the coral species on mound formation}

Growth rates of individual $S$. variabilis have been determined to vary between 0.8 and $1.25 \mathrm{~mm} \mathrm{yr}^{-1}$ in live caught field samples (Fallon et al. 2014) and between 0.5 and $3 \mathrm{~mm} \mathrm{yr}^{-1}$ (1.5 mm on average) in cultivation experiments
(Gammon et al. 2018). These growth rates are similar to the AR determined here $\left(30 \mathrm{~cm} \mathrm{kyr}^{-1}\right)$ and for S. variabilis reefs on SW Pacific seamounts $\left(21 \mathrm{~cm} \mathrm{kyr}^{-1}\right.$; Fallon et al. 2014). In comparison, D. pertusum mounds off Brazil exhibit ARs an order of magnitude higher with rates of up to $280 \mathrm{~cm} \mathrm{kyr}{ }^{-1}$. The reason for this may be the higher growth rate of $D$. pertusum. Norwegian and last glacial Mauritanian CWC mounds reveal the highest AR of up to $1600 \mathrm{~cm} \mathrm{ka}^{-1}$ (Titschack et al. 2015; Wienberg et al. 2018), which is in the same order of magnitude to the growth rate of individual $D$. pertusum with up to $2.7 \mathrm{~cm}$ $\mathrm{yr}^{-1}$ (e.g. Gass and Roberts 2011) and therefore may represent maximal CWC mound AR (Titschack et al. 2015). Thus, even though $S$. variabilis mounds are characterized by a reduced AR compared to $D$. pertusum mounds, the Bowie mound may represent nearly maximal AR of $S$. variabilis-bearing coral mounds.

Furthermore, the AR are determined in order to obtain additional information on the processes of mound formation from the species $S$. variabilis. In $D$. pertusum mounds phases of sustained coral growth are characterized by active mound formation and phases when coral growth is absent are characterized by a very low AR or even erosion (Rüggeberg et al. 2007; Frank et al. 2009; Mienis et al. 2007; Titschack et al. 2015; Wienberg et al. 2018). In contrast to most of the previously studied sedimentary $D$. pertusum mound sequences from the North Atlantic and also off Brazil (e.g. Mangini et al. 2010; Frank et al. 2011 and references therein; Henry et al. 2014; Wienberg and Titschack 2017), Bowie Mound sediments reveal intermittent intervals of sediment deposition during phases of coral absence. In particular, Bowie Mound tends to be a sediment mound with punctuated occurrences of corals possibly consolidating the sedimentary environment. This is because the amount of sediment is greater than the coralbearing units, which is different to D. pertusum and $M$. oculata mounds (Fig. 5), in which intervals solely consisting of matrix sediments are usually absent (Frank et al. 2011; Titschack et al. 2015; Wienberg et al. 2018). The calculated mSR at Bowie Mound in such coral-free intervals is considerably lower ( $8 \mathrm{vs} .30 \mathrm{~cm} \mathrm{kyr}^{-1}$ ) than within coral-bearing intervals. The mSR of matrix sediments is calculated based on the constraining coral ages, which might introduce a slight bias in the calculated SR as previous studies have shown that matrix sediments and corals may exhibit considerable age offsets of several hundred years (López Correa et al. 2012). However, this observation mirrors previous studies from the E Brazilian margin where glacial sedimentation is up to $50 \mathrm{~cm} \mathrm{kyr}^{-1}$, and thus an order of magnitude higher than Holocene sedimentation (Mahiques et al. 2004, 2007). During sea-level lowstands, the Brazilian shelf was almost entirely exposed leading to enhanced terrigenous input and increased sedimentation 
rates on the outer shelf (Mahiques et al. 2010; Albuquerque et al. 2016). At Bowie Mound, the increased sediment supply during glacial phases is baffled by the CWC framework leading to higher AR. This is well documented for $D$. pertusum mounds, where formation benefits from strong bottom currents (Rüggeberg et al. 2005; Huvenne et al. 2009; Raddatz et al. 2011) that enhance organic matter supply accompanied by increased sediment input, which is baffled in the coral framework causing enhanced mound aggregation (Huvenne et al. 2009; Mienis et al. 2007; Titschack et al. 2015). Therefore, our results may also point to a highly dynamic sedimentation regime, but also highlight that other CWCs, such as $S$. variabilis, have the ability to baffle sediment, resulting in short pulses of relatively rapid mound formation (Fig. 5).

Today bottom currents along the Brazilian shelf peak near $800 \mathrm{~m}$ water depth and occasionally exceeds $33 \mathrm{~cm} \mathrm{~s}^{-1}$ associated with the AAIW (Silveira et al. 2004). Therefore, during periods with 60-90 m lower sea-level Bowie Mound may have been exposed to stronger hydrodynamic conditions and a different intermediate watermass regime that favoured sediment and organic-matter supply to the corals. However, as we are not aware of any flow speed experiments carried out on S. variabilis, it is unknown whether high current intensities increase or reduce the growth of $S$. variabilis. Desmophyllum pertusum captures food more efficiently under slower flow velocities (Purser et al. 2010) and occurs at sites with flow speeds varying between 5 and $15 \mathrm{~cm} \mathrm{~s}^{-1}$ (Duineveld et al. 2007; Mienis et al. 2007). However, there are also reports of very large $D$. pertusum colonies that were able to survive at very high flow velocities of $60 \mathrm{~cm} \mathrm{~s}^{-1}$ (Mienis et al. 2014). Thus, we suggest that an increase in flow velocities associated with a deepening of the water-mass interface between SACW and AAIW relative to Bowie Mound during glacial periods rather actively supported than diminished CWC growth (see below).

\section{Paleoenvironmental controls on $S$. variabilis-bearing mounds}

The present physical properties of the AAIW with a seawater $\mathrm{pH}$ of 7.97 , an aragonite saturation $(\Omega)$ of 1.2 (Goyet et al. 2000), bottom-water temperature of $4.3{ }^{\circ} \mathrm{C}$ (Fig. 2; Bahr et al. 2016), salinity values of 34.3 psu and an oxygen concentration of $4.2 \mathrm{mg} \mathrm{L}^{-1}$ do not necessarily explain the currently non-active state of $S$. variabilis-bearing mounds off Brazil. Even though framework-forming CWCs may tolerate a wide range of environmental conditions, recent studies demonstrate that flourishing CWC habitats appear to be controlled by very specific environmental and oceanographic conditions (e.g. Dullo et al. 2008; Flögel et al. 2014; Hennige et al. 2014a, b), which appear to be species-specific (Wienberg and Titschack 2017). However, along the European Continental Margin flourishing CWC reefs and mounds occur in a narrow seawater density range of $27.5 \pm 0.15 \mathrm{~kg} \mathrm{~m}^{-3}$ (Dullo et al. 2008; De Mol et al. 2011; Rüggeberg et al. 2011; Flögel et al. 2014; Somoza et al. 2014; Sánchez et al. 2014). This density envelope forms due to large differences between two ambient water masses generating a strong pycnocline that favours the accumulation of organic matter from sea-surface productivity and is critical for the food supply to the corals (White et al. 2007; Dullo et al. 2008; White and Dorschel 2010). Periods of enhanced aggradation at Bowie mound predominantly fall into distinct glacial intervals and glacial terminations characterized by a lower sea level of about 60-90 m (Fig. 6; Rohling et al. 2014) implying a deepening of the water-mass boundary between the SACW and the AAIW. Such a water-mass stratification may favour the supply of particulate organic matter (POM) from high seasurface productivity settling at the pycnocline or watermass boundaries and then getting distributed by strong internal waves or along-slope bottom currents (Mienis et al. 2007; White et al. 2007; Rüggeberg et al. 2016). On the Brazilian shelf the organic-matter (OM) transport is controlled largely by sea-level changes (Albuquerque et al. 2016) and is locally enhanced due to strong sea-surface productivity (see below). Scleractinian CWCs have been observed in a number of field and laboratory studies to feed on a range of different food sources varying from particulate to dissolved OM (Van Oevelen et al. 2016a, b; Mueller et al. 2014; Gori et al. 2014; Duineveld et al. 2007; Kiriakoulakis et al. 2005). Here, we can only speculate which type of OM may have been the primary source for enhanced CWC growth and thus mound formation. A recent study reveals that the upper and middle slope off Brazil (Camps Basin) between 400 and $1300 \mathrm{~m}$ water is characterized by high total organic carbon and labile lipids concentrations (Cordeiro et al. 2018) possibly originating from enhanced primary productivity due to increased SACW upwelling on the continental shelf (Carreira et al. 2012) and thereby providing high food quality for heterotrophic organisms.

\section{High latitude linkages}

Enhanced S. variabilis mound formation occurs mostly during specific intervals of a glacial period, which are characterized by sea levels of 60-90 metres below present, increased dust supply recorded in Antarctic ice cores and increased Fe input in Southern Ocean sediments (Fig. 6; Rohling et al. 2014; Lambert et al. 2012; Martínez-García et al. 2014). Furthermore, these periods are in turn accompanied by changes in the latitudinal winds zones and high latitudinal upwelling in the South Atlantic (Anderson 


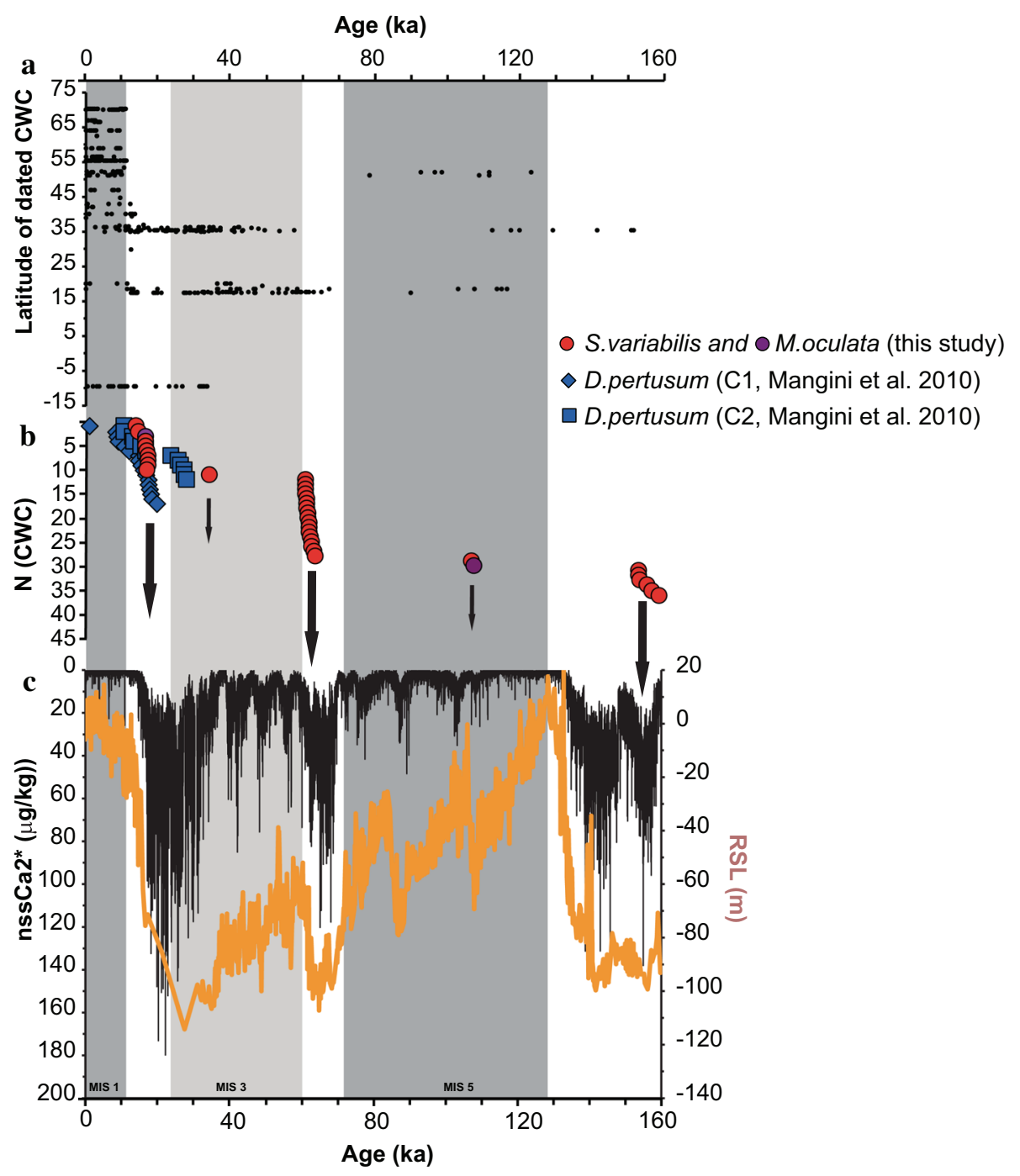

Fig. 6 a Corals ages taken from different latitudes are taken from various publications (Lindberg et al. (2005); López Correa et al. 2012; Lindberg and Mienert 2005a, b; Lindberg et al. 2007; Raddatz et al. 2014, 2016; Titschack et al. 2015; Hovland et al. 1998; Hovland and Mortensen 1999; Schröder-Ritzrau et al. 2005; Mikkelsen et al. 1982; Douarin et al. 2013; Mienis et al. 2009; Frank et al. 2009, 2004; Dorschel et al. 2007; Eisele et al. 2011; De Mol et al. 2011; Wienberg et al. 2009, 2010; Wienberg et al. 2018a, b; Frank et al. 2011; McCulloch et al. 2010; Wefing et al. 2017; $\mathrm{N} \geq 600$ ) and are plotted without uncertainties. b The coral ages of Mangini et al. (2010, D. pertusum, blue) and this study (S. variabilis, red and M. oculata

et al. 2009). Changes of polar upwelling in the Southern Ocean generally lead to a change in the chemical signature and nutrient enrichment of intermediate water masses (Anderson et al. 2009; Kiefer et al. 2006; Sarmiento et al. 2004; Spero and Lea 2002), which can also be traced at lower latitudes (Poggemann et al. 2017). Nevertheless, there is an ongoing debate, if there was an enhanced or reduced AAIW during glacial periods (Pahnke et al. 2008; Muratli et al. 2010; Ronge et al. 2015).

purple) are plotted as numbers at age. Uncertainties of the ${ }^{230} \mathrm{Th} / \mathrm{U}$ ages are smaller than the dots (Supplementary Table 1). c To track changes of the southern High latitude the sea-salt free $\mathrm{Ca}^{2+}$ concentration in the DOME C (EPICA) ice core from Lambert et al. (2012, black) is plotted as well as the sea-level curve of Rohling et al. (2014, orange). Black arrows indicate periods of mound formation pulses associated with sea-level stands $60-90 \mathrm{~m}$ lower than today and an enhanced dust input at the higher latitudes. Marine Isotope Stages (MIS) boundaries are taken from Lisiecki and Raymo (2005), except for the Pleistocene/Holocene boundary at $11.7 \mathrm{ka}$ (Walker et al. 2012)

However, biogeochemical dynamics such as the carbonate ion concentration and nutrients have been identified to contribute to CWC growth (Davies and Guinotte 2011; Findlay et al. 2014). Furthermore, it was shown that nutrient enrichments make scleractinian corals less sensitive to changes in seawater aragonite saturation (Langdon and Atkinson 2005), similar to what has been shown for food availability in CWC cultivation experiments (Büscher et al. 2017). Hence, it may be reasonable to speculate that such additional nutrient enrichments made Brazilian CWC 
less sensitive to the generally $\mathrm{CO}_{2}$ enriched AAIW (Allen et al. 2015) and thereby fostered CWC mound formation. Moreover, nutrient-rich intermediate water masses may have also fed thermocline waters at low latitudes (Raddatz et al. 2017), especially in upwelling regions (Kiefer et al. 2006; Sarmiento et al. 2004; Spero and Lea 2002). Such a scenario would also have ultimately facilitated CWC growth by increasing sea-surface productivity. Thus, even though the reason remains unclear, our data points to a linkage between Brazilian coral provinces and changes in the biogeochemical dynamics of intermediate water masses of southern origin.

Overall, our findings reveal that also other CWCs besides Desmophyllum pertusum and Madrepora oculata may at least contribute to the formation of large moundlike structures. However, as this study is only based on one sediment core, there is an urgent need to further sample different mounds (formed by different species) and mound provinces from different latitudes and different water depths along the Brazilian/Argentinian margin to clarify whether SE American coral mounds may have moved their biogeographical limit and/or water depth through time, similar to their North Atlantic counterparts.

Acknowledgements The authors thank the captain, crew members and the scientific party of RV Meteor cruise M125. JR acknowledges funding from the Focus Track A/B programme by the Goethe University Frankfurt. JT received funding by the DFG-Research Center/Cluster of Excellence "The Ocean in the Earth System" and the Cluster of Excellence "The Ocean Floor - Earth's Uncharted Interface". Data of $S$. variabilis distribution around New Zealand were provided by the NIWA Invertebrate Collection, where the specimens were collected as part of numerous research programs funded by agencies such as the New Zealand Ministry of Business Innovation and Employment, Fisheries New Zealand, New Zealand Department of Conservation and Land Information New Zealand. AR acknowledges support from Swiss National Science Foundation Project Number SNF 200021_149247. The authors are grateful to the Heidelberg University Hospital for providing access to the CT facility. We also appreciate the help by Frederik Kirst with the GIS based map. NF was supported by the DFG Grant FR1341/9-1 regarding the $\mathrm{Th} / \mathrm{U}$ dating of cold-water corals and by the DFG Grant INST 35_1143-1 FUGG, which funded the MC-ICPMS infrastructure. This work would not have been possible without the laboratory support for ${ }^{230} \mathrm{Th} / \mathrm{U}$ dating provided by René Eichstädter, and the student helpers Carla Roesch and Hanna Rosenthal. Finally, the authors thank Helen Bostock and two anonymous reviewers as well as the topical editor, whose comments considerably improved the manuscript.

\section{Compliance with ethical standards}

Conflict of interest The authors declare that they have no conflict of interest.

\section{References}

Addamo AM, Vertino A, Stolarski J, García-Jiménez R, Taviani M, Machordom A (2016) Merging scleractinian genera: The overwhelming genetic similarity between solitary Desmophyllum and colonial Lophelia. BMC Evol Biol 16:1-17

Albuquerque AL, Meyers P, Belem AL, Turcq B, Siffedine A, Mendoza U, Capilla R (2016) Mineral and elemental indicators of post-glacial changes in sediment delivery and deposition under a western boundary upwelling system (Cabo Frio, southeastern Brazil). Palaeogeogr Palaeoclimatol Palaeoecol 445:72-82

Andersen MB, Stirling CH, Zimmermann B, Halliday AN (2010) Precise determination of the open ocean ${ }^{234} \mathrm{U} /{ }^{238} \mathrm{U}$ composition. Geochem Geophys Geosys. https://doi.org/10.1029/ 2010GC003318

Anderson RF, Ali S, Bradtmiller LI, Nielsen SHH, Fleisher MQ, Anderson BE, Burckle LH (2009) Wind-driven upwelling in the Southern Ocean and the deglacial rise in atmospheric $\mathrm{CO}_{2}$. Science 323:1443-1448

Anderson OF, Guinotte JM, Rowden AA, Clark MR, Mormede S, Davies AJ, Bowden DA (2016) Field validation of habitat suitability models for vulnerable marine ecosystems in the South Pacific Ocean: Implications for the use of broad-scale models in fisheries management. Ocean Coast Manag 120:110-126

Arantes RCM, Castro CB, Pires DO, Seoane JCS (2009) Depth and water mass zonation and species associations of cold-water octocoral and stony coral communities in the southwestern Atlantic. Mar Ecol Prog Ser 397:71-79

Bahr A, Albuquerque A, and the Expedition M125 scientists (2016) South American hydrological balance and paleoceanography during the Late Pleistocene and Holocene (SAMBA)-cruise no. M125, March 21-April 15, 2016, Rio de Janeiro (Brazil)Fortaleza (Brazil). METEOR-Berichte, Bremen

Bostock HC, Tracey DM, Currie KI, Dunbar GB, Handler MR, Mikaloff Fletcher SE, Smith AM, Williams MJM (2015) The carbonate mineralogy and distribution of habitat-forming deepsea corals in the southwest pacific region. Deep Res Part I Oceanogr Res Pap 100:88-104

Büscher JV, Form AU, Riebesell U (2017) Interactive effects of ocean acidification and warming on growth, fitness and survival of the cold-water coral Lophelia pertusa under different food availabilities. Front Mar Sci 4:1-14

Cairns SD (1995) the marine Fauna of New Zeland: Scleractinia (Cnidaria: Anthozoa). New Zealand Oceanographic Institute Memior 103:1-210

Cheng H, Adkins J, Edwards RL, Boyle EA (2000) U-Th dating of deep-sea corals. Geochim Cosmochim Acta 64:2401-2416

da Carreira RS, Canuel EA, Macko SA, Lopes MB, Luz LG, Jasmim LN (2012) On the accumulation of organic matter on the southeastern Brazilian continental shelf: a case study based on a sediment core from the shelf off Rio de Janeiro. Brazilian J Oceanogr 60:75-87

da Silveira ICA, Calado L, Castro BM, Cirano M, Lima JAM, Mascarenhas AS (2004) On the baroclinic structure of the Brazil Current-Intermediate Western Boundary Current system at $22^{\circ}$ $3^{\circ} \mathrm{S}$. Geophys Res Lett $31: 1-5$

Davies AJ, Guinotte JM (2011) Global habitat suitability for framework-forming cold-water corals. PLoS ONE 6:e18483

De Mol L, Van Rooij D, Pirlet H, Greinert J, Frank N, Quemmerais F, Henriet JP (2011) Cold-water coral habitats in the Penmarc'h and Guilvinec Canyons (Bay of Biscay): Deep-water versus shallow-water settings. Mar Geol 282:40-52

De S. Carvalho M, Lopes DA, Cosme B, Hajdu E (2016) Seven new species of sponges (Porifera) from deep-sea coral mounds at 
Campos Basin (SW Atlantic). Helgol Mar Res 70:10. https://doi. org/10.1186/s10152-016-0461-Z

Duineveld GCA, Lavaleye MSS, Bergman MJN, De Stigter H, Mienis F (2007) Trophic structure of a cold-water coral mound community (Rockall Bank, NE Atlantic) in relation to the near-bottom particle supply and current regime. Bull Mar Sci $81: 449-467$

Dullo WC, Flögel S, Rüggeberg A (2008) Cold-water coral growth in relation to the hydrography of the Celtic and Nordic European continental margin. Mar Ecol Prog Ser 371:165-176

Douarin M, Elliot M, Noble SR, Sinclair D, Henry LA, Long D, Moreton SG, Murray Roberts J (2013) Growth of north-east Atlantic cold-water coral reefs and mounds during the Holocene: a high resolution U-series and ${ }^{14} \mathrm{C}$ chronology. Earth Planet Sci Lett 375:176-187

Eisele M, Frank N, Wienberg C, Hebbeln D, López Correa M, Douville E, Freiwald A (2011) Productivity controlled coldwater coral growth periods during the last glacial off Mauritania. Mar Geol 280:143-149

Fallon SJ, Thresher RE, Adkins J (2014) Age and growth of the coldwater scleractinian Solenosmilia variabilis and its reef on SW Pacific seamounts. Coral Reefs 33:31-38

Findlay HS, Hennige SJ, Wicks LC, Navas JM, Woodward EMS, Roberts JM (2014) Fine-scale nutrient and carbonate system dynamics around cold-water coral reefs in the northeast Atlantic. Sci Rep 4:1-10

Frank N, Paterne M, Ayliffe L, van Weering T, Henriet JP, Blamart D (2004) Eastern North Atlantic deep-sea corals: Tracing upper intermediate water $\Delta{ }^{14} \mathrm{C}$ during the Holocene. Earth Planet Sci Lett 219:297-309

Frank N, Ricard E, Lutringer-paquet A, Van Der Land C, Colin C, Blamart D, Foubert A, Van Rooij D, Henriet J (2009) The Holocene occurrence of cold water corals in the NE Atlantic: Implications for coral carbonate mound evolution. Mar Geol 266:129-142

Frank N, Freiwald A, López Correa M, Wienberg C, Eisele M, Hebbeln D, Van Rooij D, Henriet JP, Colin C, van Weering T, de Haas H, Buhl-Mortensen P, Roberts JM, De Mol B, Douville E, Blamart D, Hatté C (2011) Northeastern Atlantic cold-water coral reefs and climate. Geology 39:743-746

Freiwald A (2002) Reef-forming cold-water corals. In: Wefer G, Billett D, Hebbeln D, Jørgensen BB, Schlüter M, van Weering TCE (eds) Ocean Margin Systems. Springer, Berlin, pp 365-385

Freiwald A, Beuck L, Rüggeberg A, Taviani M, Hebbeln D (2009) The white coral community in the central Mediterranean Sea revealed by ROV surveys. Oceanography 22:58-74

Freiwald A, Rogers A, Hall-Spencer J, Guinotte JM, Davies AJ, Yesson C, Martin CS, Weatherdon LV (2017) Global distribution of cold-water corals (version 5.0). Fifth update to the dataset in Freiwald et al. (2004) by UNEP-WCMC, in collaboration with Andre Freiwald and John Guinotte. Cambridge (UK): UN Environment World Conservation Monitoring Centre. http:// data.unep-wcmc.org/datasets/3

Freiwald A (unpublished) GloSS: Global Register of Species associated to habitat-forming cold-water Scleractinia. Database

Flögel S, Dullo WC, Pfannkuche O, Kiriakoulakis K, Rüggeberg A (2014) Geochemical and physical constraints for the occurrence of living cold-water corals. Deep Res Part II Top Stud Oceanogr 99:19-26

Gammon MJ, Cummings VJ, Davy SK, Marriott PM, Tracey DM (2018) The physiological response of the deep-sea coral Solenosmilia variabilis to ocean acidification. PeerJ 6:e5236

Gass SE, Roberts JM (2011) Growth and branching patterns of Lophelia pertusa (Scleractinia) from the North Sea. J Mar Biol Assoc United Kingdom 91:831-835
Gori A, Grover R, Orejas C, Sikorski S, Ferrier-Pagès C (2014) Uptake of dissolved free amino acids by four cold-water coral species from the Mediterranean Sea. Deep Res Part II Top Stud Oceanogr 99:42-50

Goyet C, Healy R, Ryan PJ (2000) Global distribution of total inorganic carbon and total alkalinity below the deepest winter mixed layer depths, ORNL/CDIAC-127, Carbon Dioxide Inf. Anal. Cent., Oak Ridge Natl. Lab., U.S. Dep. of Energy, Oak Ridge, Tenn

Hebbeln D, Wienberg C, Wintersteller P, Freiwald A, Becker M, Beuck L, Dullo C, Eberli GP, Glogowski S, Matos L, Forster N, Reyes-Bonilla H, Taviani M (2014) Environmental forcing of the Campeche cold-water coral province, southern Gulf of Mexico. Biogeosciences 11:1799-1815

Hebbeln D, da Portilho-Ramos RC, Wienberg C, Titschack J (2019) The Fate of Cold-Water Corals in a Changing World: A Geological Perspective. Front Mar Sci 6:1-8

Hennige SJ, Wicks LC, Kamenos NA, Bakker DCE, Findlay HS, Dumousseaud C, Roberts JM (2014a) Short-term metabolic and growth responses of the cold-water coral Lophelia pertusa to ocean acidification. Deep Res Part II Top Stud Oceanogr 99:27-35

Hennige SJ, Morrison CL, Form AU, Büscher J, Kamenos NA, Roberts JM (2014b) Self-recognition in corals facilitates deepsea habitat engineering. Sci Rep 4:6782

Henry LA, Frank N, Hebbeln D, Wienberg C, Robinson L, de van Flierdt T, Dahl M, Douarin M, Morrison CL, Correa ML, Rogers AD, Ruckelshausen M, Roberts JM (2014) Global ocean conveyor lowers extinction risk in the deep sea. Deep Res Part I Oceanogr Res Pap 88:8-16

Hovland M, Mortensen PB (1999) Norwegian Coral Reefs and Processes in the Seabed. John Grieg, Bergen, Norway

Hovland M, Mortensen PB, Brattegard T, Strass P, Rokoengen K (1998) Ahermatypic coral banks off mid-Norway: Evidence for a link with seepage of light hydrocarbons. Palaios 13:189-200

Huvenne VAI, Masson DG, Wheeler AJ (2009) Sediment dynamics of a sandy contourite: The sedimentary context of the Darwin cold-water coral mounds, Northern Rockall Trough. Int J Earth Sci 98:865-884

Kiefer T, McCave IN, Elderfield H (2006) Antarctic control on tropical Indian Ocean sea surface temperature and hydrography. Geophys Res Lett 33:10-15

Kitahara MV (2006) Novas ocorrências de corais azooxantelados (Anthozoa, Scleractinia) na plataforma e talude continental do sul do Brasil (25-34o S). Biotemas 19:55-63

Kitahara MV (2007) Species richness and distribution of azooxanthellate Scleractinia in Brazil. Bull Mar Sci 81:497-518

Kiriakoulakis K, Fisher E, Wolff GA, Freiwald A, Grehan A, Roberts JM (2005) Lipids and nitrogen isotopes of two deep-water corals from the North-East Atlantic: initial results and implication for their nutrition. In: Freiwald A, Roberts JM (eds) Cold-Water Corals and Ecosystems. Springer-Verlag, Berlin Heidelberg, pp 715-729

Koslow JA, Gowlett-Holmes K, Lowry JK, O'Hara T, Poore GCB, Williams A (2001) Seamount benthic macrofauna off southern Tasmania: Community structure and impacts of trawling. Mar Ecol Prog Ser 213:111-125

Langdon $\mathrm{C}$, Atkinson $\mathrm{MJ}$ (2005) Effect of elevated $\mathrm{pCO}_{2}$ on photosynthesis and calcification of corals and interactions with seasonal change in temperature/irradiance and nutrient enrichment. J Geophys Res C Ocean 110:1-16

Lambert F, Bigler M, Steffensen JP, Hutterli M, Fischer H (2012) Centennial mineral dust variability in high-resolution ice core data from Dome C, Antarctica. Clim Past 8:609-623

Lewis E, Wallace DWR (1998) Program developed for $\mathrm{CO}_{2}$ system calculations, ORNL/CDIAC-105, Carbon Dioxide Inf. Anal. 
Cent., Oak Ridge Natl. Lab., U.S. Dep. of Energy, Oak Ridge, Tenn

López Correa M, Montagna P, Joseph N, Rüggeberg A, Fietzke J, Flögel S, Dorschel B, Goldstein SL, Wheeler A, Freiwald A (2012) Preboreal onset of cold-water coral growth beyond the Arctic Circle revealed by coupled radiocarbon and U-series dating and neodymium isotopes. Quat Sci Rev 34:24-43

Lindberg B, Mienert J (2005a) Sedimentological and geochemical environment of the Fugløy Reef off northern Norway. In: Freiwald A, Roberts JM (eds) Cold-Water Corals and Ecosystems. Springer Berlin Heidelberg, Berlin, Heidelberg, pp 633-650

Lindberg B, Mienert J (2005b) Postglacial carbonate production by cold-water corals on the Norwegian shelf and their role in the global carbonate budget. Geology 33:537-540

Lindberg B, Berndt C, Mienert J (2007) The Fugloy Reef at $70^{\circ} \mathrm{N}$; acoustic signature, geologic, geomorphologic and oceanographic setting. Int J Earth Sci 96:201-213

Lisiecki LE, Raymo ME (2005) A Pliocene-Pleistocene stack of 57 globally distributed benthic $\delta 18 \mathrm{O}$ records. Paleoceanography 20:1-17

Lumsden SE, Hourigan TF, Bruckner AW, Dorr G (2007) The state of deep coral ecosystems of the United States, NOAA Technical Memorandum CRCP-3, Silver Spring MD

Mangini A, Godoy JM, Godoy ML, Kowsmann R, Santos GM, Ruckelshausen M, Schroeder-Ritzrau A, Wacker L (2010) Deep sea corals off Brazil verify a poorly ventilated Southern Pacific Ocean during H2, H1 and the Younger Dryas. Earth Planet Sci Lett 293:269-276

Mahiques MM, Tessler MG, Maria Ciotti A, Da Silveira ICA, E Sousa SHDM, Figueira RCL, Tassinari CCG, Furtado VV, Passos RF (2004) Hydrodynamically driven patterns of recent sedimentation in the shelf and upper slope off Southeast Brazil. Cont Shelf Res 24:1685-1697

Mahiques MM, Fukumoto MM, Silveira ICA, Figueira RCL, Bícego MC, Lourenço RA, Mello-E-Sousa SH (2007) Sedimentary changes on the Southeastern Brazilian upper slope during the last 35,000 years. An Acad Bras Cienc 79:171-181

Mahiques M, Tessler MG, Antonio F, Toledo DL, Burone L, Cesar R, Figueira L (2010) The southern Brazilian shelf: general characteristics, Quaternary evolution and sediment distribution. Brazilian J Oceanogr 58:25-34

Martínez-García A, Sigman DM, Ren H, Anderson RF, Straub M, Hodell DA, Jaccard SL, Eglinton TI, Haug GH (2014) Iron fertilization of the subantarctic ocean during the last ice age. Science (80-) 343:1347-1350

McCulloch M, Taviani M, Montagna P, López Correa M, Remia A, Mortimer G (2010) Proliferation and demise of deep-sea corals in the Mediterranean during the Younger Dryas. Earth Planet Sci Lett 298:143-152

Mémery L, Arhan M, Alvarez-Salgado XA, Messias MJ, Mercier H, Castro CG, Rios AF (2000) The water masses along the western boundary of the south and equatorial Atlantic. Prog Oceanogr 47:69-98

Mienis F, de Stigter HC, White M, Duineveld G, de Haas H, van Weering TCE (2007) Hydrodynamic controls on cold-water coral growth and carbonate-mound development at the SW and SE Rockall Trough Margin, NE Atlantic Ocean. Deep Res Part I Oceanogr Res Pap 54:1655-1674

Mienis F, van der Land C, de Stigter HC, van de Vorstenbosch M, de Haas H, Richter T, van Weering TCE (2009) Sediment accumulation on a cold-water carbonate mound at the Southwest Rockall Trough margin. Mar Geol 265:40-50

Mienis F, Duineveld GCA, Davies AJ, Lavaleye MMS, Ross SW, Seim H, Bane J, Van Haren H, Bergman MJN, De Haas H, Brooke S, Van Weering TCE (2014) Cold-water coral growth under extreme environmental conditions, the Cape Lookout area, NW Atlantic. Biogeosciences 11:2543-2560

Mikkelsen N, Erlenkeuser H, Killingley JS, Berger WH (1982) Norwegian corals: radiocarbon and stable isotopes in Lophelia pertusa. Boreas 11:163-171

Mueller CE, Larsson AI, Veuger B, Middelburg JJ, Van Oevelen D (2014) Opportunistic feeding on various organic food sources by the cold-water coral Lophelia pertusa. Biogeosciences 11:123-133

Muratli JM, Chase Z, Mix AC, McManus J (2010) Increased glacialage ventilation of the Chilean margin by Antarctic Intermediate Water. Nat Geosci 3:23-26

Pahnke K, Goldstein SL, Hemming SR (2008) Abrupt changes in Antarctic Intermediate Water circulation over the past 25,000 years. Nat Geosci 1:870-874

Piola AR, Campos EJD, Möller OO, Charo M, Martinez C (2002) Subtropical Shelf Front off eastern South America. J Geophys Res Ocean 105:6565-6578

Pires DO (2007) The azooxanthellate coral fauna of Brazil. Conserv Adapt Manag seamount Deep coral Ecosyst 265-272

Pires DO, Silva JC, Bastos ND (2014) Reproduction of deep-sea reefbuilding corals from the southwestern Atlantic. Deep Res Part II Top Stud Oceanogr 99:51-63

Purser A, Larsson AI, Thomsen L, van Oevelen D (2010) The influence of flow velocity and food concentration on Lophelia pertusa (Scleractinia) zooplankton capture rates. J Exp Mar Bio Ecol 395:55-62

Poggemann DW, Hathorne EC, Nürnberg D, Frank M, Bruhn I, Reißig S, Bahr A (2017) Rapid deglacial injection of nutrients into the tropical Atlantic via Antarctic Intermediate Water. Earth Planet Sci Lett 463:118-126

Raddatz J, Rüggeberg A, Margreth S, Dullo WC (2011) Paleoenvironmental reconstruction of Challenger Mound initiation in the Porcupine Seabight, NE Atlantic. Mar Geol 282:79-90

Raddatz J, Rüggeberg A, Liebetrau V, Foubert A, Hathorne EC, Fietzke J, Eisenhauer A, Dullo WC (2014) Environmental boundary conditions of cold-water coral mound growth over the last 3 million years in the Porcupine Seabight, Northeast Atlantic. Deep Res Part II Top Stud Oceanogr 99:227-236

Raddatz J, Nürnberg D, Tiedemann R, Rippert N (2017) Southeastern marginal West Pacific Warm Pool sea-surface and thermocline dynamics during the Pleistocene (2.5-0.5 Ma). Palaeogeogr Palaeoclimatol Palaeoecol 471:144-156

Raddatz J, Liebetrau V, Trotter J, Rüggeberg A, Flögel S, Dullo WC, Eisenhauer A, Voigt S, McCulloch M (2016) Environmental constraints on Holocene cold-water coral reef growth off Norway: insights from a multiproxy approach. Paleoceanography 31:1350-1367

Raddatz J, Rüggeberg A (2019) Constraining past environmental changes of cold-water coral mounds with geochemical proxies in corals and foraminifera. The Depositional Record. https://doi. org/10.1002/dep2.98

Roberts JM, Wheeler AJ, Freiwald A (2006) Reefs of the deep: The biology and geology of cold-water coral ecosystems. Science 312:543-547

Roberts JM, Wheeler A, Freiwald A, Cairns S (2009) Cold-water corals: the biology and geology of deep-sea coral habitats. Cambridge University Press, Cambridge

Rodrigues RR, Rothstein LM, Wimbush M (2007) Seasonal Variability of the South Equatorial Current Bifurcation in the Atlantic Ocean: A Numerical Study. J Phys Oceanogr 37:16-30

Rohling EJ, Foster GL, Grant KM, Marino G, Roberts AP, Tamisiea ME, Williams F (2014) Sea-level and deep-sea-temperature variability over the past 5.3 million years. Nature 508:477-482

Ronge TA, Steph S, Tiedemann R, Prange M, Merkel U, Nürnberg D, Kuhn G (2015) Pushing the boundaries: Glacial/interglacial 
variability of intermediate and deep waters in the southwest Pacific over the last 350,000 years. Paleoceanography 30:23-38

Rüggeberg A, Dorschel B, Dullo WC, Hebbeln D (2005) Sedimentary patterns I the vicinity of a carbonate mound in the Hovland Mound Province, Northern Porcupine Sebaight. In: Freiwald A, Roberts JM (eds) Cold-water Corals and Ecosystems. SpringerVerlag, Berlin Heidelberg, pp 87-112

Rüggeberg A, Dullo WC, Dorschel B, Hebbeln D (2007) Environmental changes and growth history of a cold-water carbonate mound (Propeller Mound, Porcupine Seabight). Int J Earth Sci 96:57-72

Rüggeberg A, Flögel S, Dullo WC, Hissmann K, Freiwald A (2011) Water mass characteristics and sill dynamics in a subpolar coldwater coral reef setting at Stjernsund, northern Norway. Mar Geol 282:5-12

Rüggeberg A, Flögel S, Dullo WC, Raddatz J, Liebetrau V (2016) Paleoseawater density reconstruction and its implication for cold-water coral carbonate mounds in the northeast Atlantic through time. Paleoceanography 31:365-379

Sánchez F, González-Pola C, Druet M, García-Alegre A, Acosta J, Cristoba J, Parra S, Ríos P, Altuna Á, Gómez-Ballesteros M, Muñoz-Recio A, Rivera J, Díaz del Río G (2014) Habitat characterization of deep-water coral reefs in La Gaviera Canyon (Avilés Canyon System, Cantabrian Sea). Deep Res Part II Top Stud Oceanogr 106:118-140

Sarmiento JL, Gruber N, Brzezinski MA, Dunne JP (2004) Highlatitude controls of thermocline nutrients and low latitude biological productivity. Nature 427:56-60

Schlitzer R. (2017) Ocean Data View, http://odv.awi.de

Schröder-Ritzrau A, Freiwald A, Mangini A (2005) U/Th-dating of deep-water corals from the eastern North Atlantic and the western Mediterranean Sea. In: Freiwald A, Roberts JM (eds) Cold-water Corals and Ecosystems. Springer, Berlin, pp $157-172$

Skornitzke S, Raddatz J, Bahr A, Pahn G, Kauczor H-U, Stiller W (2019) Experimental application of an automated alignment correction algorithm for geological CT imaging: phantom study and application to sediment cores from cold-water coral mounds. Eur Radiol Exp 3:0-7

Somoza L, Ercilla G, Urgorri V, León R, Medialdea T, Paredes M, Gonzalez FJ, Nombela MA (2014) Detection and mapping of cold-water coral mounds and living Lophelia reefs in the Galicia Bank, Atlantic NW Iberia margin. Mar Geol 349:73-90

Spero HJ, Lea DW (2002) The cause of carbon isotope minimum events on glacial terminations. Science 296:522-525

Stalling D, Westerhoff M, Hege HC (2005) Amira: A highly interactive system for visual data analysis. In: Hansen CD, Johnson CR (eds) Visualization Handbook. Elsevier Butterworth-Heinemann, Burlington/Oxford, pp 749-767

Stramma L, England M (1999) On the water masses and mean circulation of the South Atlantic Ocean. J Geophys Res Ocean 104:20863-20883

Sumida PYG, Yoshinaga MY, Madureira LASP, Hovland M (2004) Seabed pockmarks associated with deepwater corals off SE Brazilian continental slope, Santos Basin. Mar Geol 207:159-167

Sverdrup HU, Johnson MW, Fleming RH (1942) The oceans, their physics, chemistry, and general biology. Prentice-Hall, New York

Taviani M, Angeletti L, Foglini F, Corselli C, Nasto I, Pons-Branchu E, Montagna P (2019) U/Th dating records of cold-water coral colonization in submarine canyons and adjacent sectors of the southern Adriatic Sea since the Last Glacial Maximum. Prog Oceanogr 175:300-308

Thresher RE, Tilbrook B, Fallon S, Wilson NC, Adkins J (2011) Effects of chronic low carbonate saturation levels on the distribution, growth and skeletal chemistry of deep-sea corals and other seamount megabenthos. Mar Ecol Prog Ser 442:87-96

Thresher R, Althaus F, Adkins J, Gowlett-Holmes K, Alderslade P, Dowdney J, Cho W, Gagnon A, Staples D, McEnnulty F, Williams A (2014) Strong depth-related zonation of megabenthos on a rocky continental margin $(\sim 700-4000 \mathrm{~m})$ off Southern Tasmania, Australia. PLoS One 9:e85872

Titschack J, Baum D, de Pol-Holz R, López Correa M, Forster N, Flögel S, Hebbeln D, Freiwald A (2015) Aggradation and carbonate accumulation of Holocene Norwegian cold-water coral reefs. Sedimentology 62:1-26

Titschack J, Fink HG, Baum D, Wienberg C, Hebbeln D, Freiwald A (2016) Mediterranean cold-water corals - an important regional carbonate factory? Depos Rec 2:74-96

Tracey DM, Rowden AA, Mackay KA, Compton T (2011) Habitatforming cold-water corals show affinity for seamounts in the New Zealand region. Mar Ecol Prog Ser 430:1-22

Tracey D, Bostock H, Currie K, Mikaloff-Fletcher S, Williams M, Hadfield M, Neil H, Guy C, Cummings V (2013) The potential impact of ocean acidification on deep-sea corals and fisheries habitat in New Zealand waters. New Zealand aquatic environment and biodiversity Report No. 117. 2013:101

Trotter JA, Pattiaratchi C, Montagna P, Taviani M, Falter J, Thresher R, Hosie A, Haig D, Foglini F, Hua Q, McCulloch MT (2019) First ROV Exploration of the Perth Canyon: Canyon Setting, Faunal Observations, and Anthropogenic Impacts. Front Mar Sci $6: 1-24$

Van Oevelen D, Mueller CE, Lundälv T, Middelburg JJ (2016a) Food selectivity and processing by the cold-water coral Lophelia pertusa. Biogeosciences 13:5789-5798

van Oevelen D, Grehan A, Mohn C, Soetaert K, Rengstorf A (2016b) Ecosystem engineering creates a direct nutritional link between 600 -m deep cold-water coral mounds and surface productivity. Sci Rep 6:1-9

Venancio IM, Belem AL, dos Santos THR, Zucchi MR, Azevedo AEG, Capilla R, Albuquerque ALS (2014) Influence of continental shelf processes in the water mass balance and productivity from stable isotope data on the Southeastern Brazilian coast. J Mar Syst 139:241-247

Viana AR, Faugères JC, Kowsmann RO, Lima JAM, Caddah LFG, Rizzo JG (1998) Hydrology, morphology and sedimentology of the Campos continental margin, offshore Brazil. Sediment Geol $115: 133-157$

Viana AR, De Almeida W, De Almeida CW (2008) Upper slope sands: Late Quaternary shallow-water sandy contourities of Campos Basin, SW Atlantic Margin. Geol Soc London, Mem 22:261-270

Walker MJC, Berkelhammer M, Björck S, Cwynar LC, Fisher DA, Long AJ, Lowe JJ, Newnham RM, Rasmussen SO, Weiss H (2012) Formal subdivision of the Holocene Series/Epoch: A Discussion Paper by a Working Group of INTIMATE (Integration of ice-core, marine and terrestrial records) and the Subcommission on Quaternary Stratigraphy (International Commission on Stratigraphy). J Quat Sci 27:649-659

Wang H, Lo Iacono C, Wienberg C, Titschack J, Hebbeln D (2019) Cold-water coral mounds in the southern Alboran Sea (western Mediterranean Sea): Internal waves as an important driver for mound formation since the last deglaciation. Mar Geol 412:1-18

Wefing A-M, Arps J, Blaser P, Wienberg C, Hebbeln D, Frank N (2017) High precision U-series dating of scleractinian cold-water corals using an automated chromatographic $\mathrm{U}$ and Th extraction. Chem Geol 475:140-148

White M, Mohn C, Stigter H, Mottram G (2005) Deep-water coral development as a function of hydrodynamics and surface productivity around the submarine banks of the Rockall Trough, 
NE Atlantic. In: Freiwald A, Roberts JM (eds) Cold-water corals and ecosystems. Springer, Berlin, pp 503-514

White M, Dorschel B, Wheeler AJ, Foubert A, Hebbeln D (2007) Hydrodynamics and cold-water coral facies distribution related to recent sedimentary processes at Galway Mound west of Ireland. Mar Geol 244:184-195

White M, Dorschel B (2010) The importance of the permanent thermocline to the cold water coral carbonate mound distribution in the NE Atlantic. Earth Planet Sci Lett 296:395-402

Wienberg C, Hebbeln D, Fink HG, Mienis F, Dorschel B, Vertino A, López Correa M, Freiwald A (2009) Scleractinian cold-water corals in the Gulf of Cádiz-First clues about their spatial and temporal distribution. Deep Res Part I Oceanogr Res Pap 56:1873-1893

Wienberg C, Frank N, Mertens KN, Stuut JB, Marchant M, Fietzke J, Mienis F, Hebbeln D (2010) Glacial cold-water coral growth in the Gulf of Cádiz: Implications of increased palaeo-productivity. Earth Planet Sci Lett 298:405-416

Wienberg C, Titschack J (2017) Framework-forming scleractinian cold-water corals through space and time: A late Quaternary
North Atlantic perspective. In: Rossi S, Bramanti L, Gori A, Orejas C (eds) Marine Animal Forests: the Ecology of Benthic Biodiversity Hotspots. Springer, pp. 699-732. https://doi.org/10. 1007/978-3-319-17001-5_16-1

Wienberg C, Titschack J, Freiwald A, Frank N, Lundälv T, Taviani M, Beuck L, Schröder-Ritzrau A, Krengel T, Hebbeln D (2018) The giant Mauritanian cold-water coral mound province: Oxygen control on coral mound formation. Quat Sci Rev $185: 135-152$

Worthington LV (1976) On the North Atlantic Circulation. John Hopkins University Press, Baltimore

Zibrowius H (1973) Scléractiniaries des Iles Saint Paul de Amsterdam (sud de l'Océan Indien). Tethys 5:747-777

Zibrowius H (1980) Les Scleractiniaires de la Méditerranée et de l'Atlantique nord- oriental. Memoires de 1'Institut Oceanographique (Monaco) 11:1-284 